\title{
Forest Structure and the Species Composition of the Parque Estadual Mata Atlântica, Located in Goiás State, Brazil
}

\author{
Ismael Martins Pereira $\mathbb{D}^{1},{ }^{1}$ Jovan Martins Rios, ${ }^{1}$ Vagner Santiago do Vale, ${ }^{1}$ \\ Vera Lúcia Gomes-Klein, ${ }^{2}$ Ademilson Coneglian, ${ }^{1}$ and Ednaldo Cândido Rocha ${ }^{1}$ \\ ${ }^{1}$ Universidade Estadual de Goiás (UEG), Câmpus Ipameri, Ipameri, GO, Brazil \\ ${ }^{2}$ Department de Botânica, Universidade Federal de Goiás (UFG), Avenida Esperança, S/N, Câmpus Samambaia (Campus II), \\ Goiânia, GO, Brazil \\ Correspondence should be addressed to Ismael Martins Pereira; ismaelmpufg@gmail.com
}

Received 22 August 2017; Accepted 10 December 2017; Published 15 January 2018

Academic Editor: L. M. Chu

Copyright (C) 2018 Ismael Martins Pereira et al. This is an open access article distributed under the Creative Commons Attribution License, which permits unrestricted use, distribution, and reproduction in any medium, provided the original work is properly cited.

\begin{abstract}
The Parque Estadual Mata Atlântica (PEMA), Goiás state, Brazil, is an Atlantic Forest reserve which has not been studied yet. The aims were to investigate plant biodiversity and characterize the flora to support the management plan. We adopt the point-centered quarter method to inventory the tree-shrub and lianas with the diameter at breast height more than or equal to $5 \mathrm{~cm}$. The study was performed through $1.86 \mathrm{~km}$ of transect with 187 sampled points. We sampled 748 individuals and identified 109 species, 82 genera, and 51 families. The Shannon-Wiener diversity index $\left(H^{\prime}\right)$ was 3.97, and Pielou's evenness $(J)$ was 0.846 , both considered high. The Fabaceae family was the most diverse with 20 species. Aspidosperma polyneuron, an endangered tree species, had greater relative dominance and importance value. The floristic similarity analysis indicated that the PEMA vegetation belongs to the seasonal forest, currently very fragmented and degraded. Due to several anthropogenic threats, we suggest the following recommendations: prevent the exploitation of species, avoid hunting, control invasive grasses, prevent forest fires, and promote environmental education. This study demonstrates the importance of PEMA for species conservation. Therefore, this study is essential for the development of management plan and the conservation of PEMA biodiversity.
\end{abstract}

\section{Introduction}

The Atlantic Forest Domain (AFD) is the second largest American rainforest [1], recognized as a global biodiversity hotspot [2]. This forest originally covered ca. 148 million hectares; approximately $92 \%$ is distributed in 17 Brazilian states, and the remainder belongs to Argentina and Paraguay $[3,4]$.

The classification of Brazilian vegetation recognizes two groups in the Atlantic Forest Domain: rainforests and seasonal forests [5]. The rainforests occur near the coast. The Seasonal Dry Neotropical Forests (SDNF) are inland in the country as enclaves in the Cerrado and Caatinga biomes $[5,6]$. These forests occur in disjunct patches scattered throughout the Neotropic, and the major biomes where SDNF is in contact are the savanna woodland (e.g., the
Cerrado), lowland tropical rainforest, and montane forest [7]. An estimate indicates that the extent of SDNF makes up about $15 \%$ of the Cerrado area (ca. $300,000 \mathrm{~km}^{2}$ ) in small areas or up to tens of thousands of square kilometers, for example, "Mato Grosso Goiano" in central region of Goiás state and "Triângulo Mineiro" in Minas Gerais state [8]. Other disjunctions of SDNF in the valleys of São Francisco and Paraná rivers in Goiás and Tocantins states are not measured [9].

Despite the importance of the Atlantic Forest, it is very fragmented and degraded, and therefore the remnants are important for conservation [10]. Thus, the conservation of AFD becomes a challenge due to various factors (fires, deforestations, and fragmentation), especially because of the high level of human disturbance [11]. It is necessary to 
conduct floristic studies and to create new reserves, especially in higher diversity areas [12-15].

The aims of the present study were to inventory the flora of tree-shrubs and lianas of Parque Estadual Mata Atlântica (PEMA), located in the Água Limpa municipality, Goiás state, Brazil, to improve the knowledge of local flora, and to support the management plan of PEMA.

\section{Materials and Methods}

2.1. Characterization of the Study Area. PEMA was established by Decree 6.442 of April of 2006. The PEMA is managed by "Secretaria do Meio Ambiente, Recursos Hídricos, Infraestrutura, Cidades, e Assuntos Metropolitanos (SECIMA)" of Goiás State, Brazil. It covers about 940 hectares and is located in the municipality of Água Limpa, southern region of Goiás state $\left(18^{\circ} 21^{\prime} 03^{\prime \prime} S ; 48^{\circ} 76^{\prime} 85^{\prime \prime} \mathrm{W}\right.$ ) (Figure 1).

The average elevation of PEMA is $611 \mathrm{~m}$, bordered by Brisas Reservoir that belongs to the Itumbiara hydroelectric dam, Goiás, Brazil (Figure 1). The soils are Dystrophic Litholic Neosols-Eutrophic Haplic Cambisols to red Eutrophic Argisols [16]. The climate is characterized by two distinct seasons, a hot and rainy season from November to March and a dry season from April to October [17]. The climate is classified as Aw (Köppen) (tropical with summer rains). The average annual temperature is $23.5^{\circ} \mathrm{C}$, and average annual rainfall is $1.314 \mathrm{~mm}$ for Água Limpa city, Goiás [17].

2.2. Vegetation Inventory and Data Analysis. We used the point-centered quarter method (PCQM) for phytosociological survey. The distance between sampling points was $10 \mathrm{~m}$, totaling 187 sampling points in $1.86 \mathrm{~km}$ of nine transects. We registered the distance from the point, height, and diameter from all trees, shrubs, and lianas, live or dead, whose diameter at breast height $(\mathrm{DBH})$ was equal to or larger than $5 \mathrm{~cm}$. We analyzed the following phytosociological parameters: Shannon-Wiener diversity index $\left(H^{\prime}\right)$, Pielou's evenness $(J)$ [18], relative density $(\mathrm{RD})$, relative dominance (RDo), relative frequency (RF), and importance value (IV) [19].

The species accumulation curve was constructed to evaluate sampling sufficiency. The estimation of species richness was performed using the Jackknife 1 estimator [20] in the EstimateS program version 9.1 [21]. These results were used for construction of observed (Mao Tao) and estimated species accumulation curves.

The presence/absence matrix for all species founded in PEMA was compared with other domains: Atlantic Forest Domain (AFD), including Seasonal Dry Neotropical Forests (SDNF), Cerrado, and Amazonian Rainforest (ARF). The categorization of the main phytophysiognomy in which the species occurs was based on the literature records $[8,22-$ 24]. This data matrix was used to perform a cluster analysis using the Jaccard Similarity Index as a measure of similarity between PEMA and the other biomes by Unweighted Pair Group Method with Arithmetic Mean (UPGMA). Statistical analyses were done in $\mathrm{R}$ program ( $\mathrm{R}$ Core Team, 2017) (https://www.R-project.org/), using the "vegan" package (Oksanen et al., 2017) (https://CRAN.R-project.org/package= vegan) (last access in 04/09/2017).
The individuals were identified in situ or by botanical samples in laboratory analysis. The fertile botanical material will be deposited in the Universidade Estadual de Goiás (UEG) herbarium. Species nomenclature was standardized according to the Plant List (http://www.theplantlist.org/), the International Plant Name Index (http://www.ipni.org), and Jardim Botânico do Rio de Janeiro (http://floradobrasil.jbrj .gov.br/reflora/floradobrasil/FB90947). The APG IV was used for the botanic classification of species, genera, and families [25].

\section{Results}

The study was performed through $1.86 \mathrm{~km}$ of transect with 187 sampled points. We sampled 748 individuals and identified 109 species, 82 genera, and 51 families. The Shannon-Wiener diversity index $\left(H^{\prime}\right)$ was 3.97 , and Pielou's evenness $(J)$ was 0.846 . The estimated richness was higher than the observed richness (Figure 2).

The most representative families in species number were Fabaceae (20), Malvaceae (7), Myrtaceae (6), Apocynaceae (5), Bignoniaceae, Euphorbiaceae, Rubiaceae, and Sapindaceae, with four species each. Chrysobalanaceae, Meliaceae, Moraceae, Rutaceae, and Salicaceae were represented by three species each, totaling $63 \%$ of all identified species (Figure 3 ).

The species with the highest relative density (RD) were Casearia gossypiosperma (7.63\%), Myrcia splendens (5.62\%), Metrodorea stipularis (4.42\%), Myracrodruon urundeuva (3.75\%), Syagrus oleracea (3.75\%), Anadenanthera colubrine/Myrcia rostrata (3.61\%), Trichilia claussenii (2.75\%), Apuleia leiocarpa (2.68\%), and Casearia rupestris (2.41\%). These species contributed with approximately $40.43 \%$ of the living individuals (Table 1). Another 39 species contributed with only a single individual. The four species with highest relative density (RD) are the same with regard to relative frequency (RF): C. gossypiosperma (6.12\%), M. splendens (5.65\%), M. stipularis, and S. oleracea (3.93\%). The species with highest values of the relative dominance (RDo) were Aspidosperma polyneuron (15.04\%), followed by A. colubrina (10.56\%), Hymenaea courbaril (7.99\%), Ceiba speciosa (6.68\%), Enterolobium contortisiliquum (5.36\%), Cariniana estrellensis (5.06\%), Attalea phalerata (4.24\%), Apuleia leiocarpa (3.28\%), Aspidosperma discolor (3.27\%), and M. urundeuva (2.38\%). The sum of top 10 species in terms of IV corresponded to $43.21 \%$ from the total. Dead individuals presented the highest IV and the second largest relative density $(\mathrm{RD}=7.23)$.

Six endangered plants were identified in the PEMA* (A. leiocarpa, garapa; Astronium fraxinifolium, gonçalo alves; A. polyneuron, peroba rosa; Bowdichia virgilioides Kunth, sucupira preta; Cedrela fissilis, cedro; and M. urundeuva, aroeira) (Table 1).

Cluster analysis of floristic similarities showed that about $80 \%$ of the PEMA species were shared with the SDNF. The PEMA species compared to other biomes showed two welldefined groups (PEMA-Dry Neotropical Seasonal Forest and AFD), indicating $>75 \%$ of species similarity from PEMA with AFD (Figure 4). Additionally, $68 \%$ of the PEMA species also occur in Cerrado (Figure 4). The group including only 


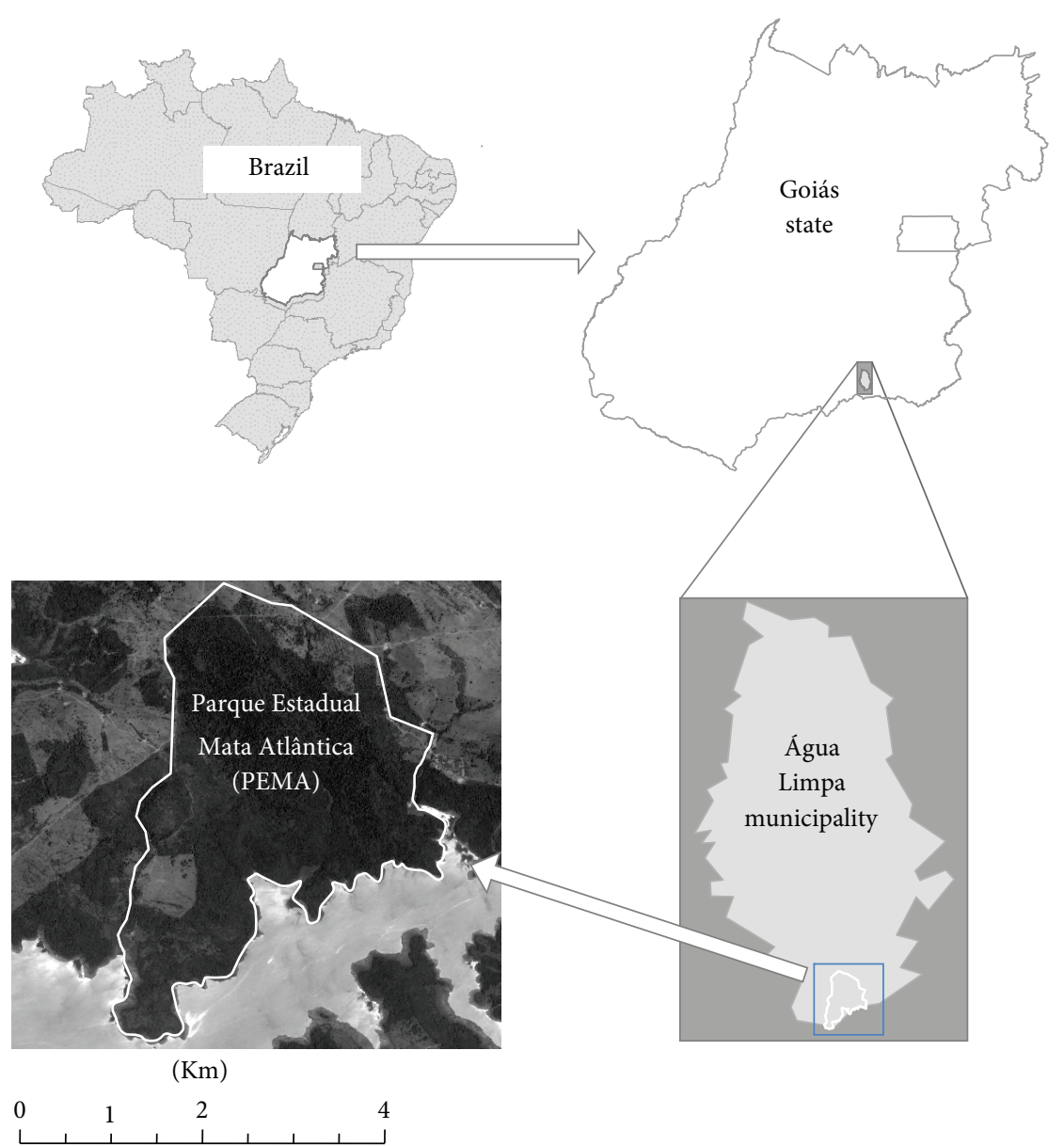

Figure 1: Parque Estadual Mata Atlântica (PEMA) in Água Limpa municipality, Goiás state, Brazil. Satellite image: Google Earth, 2016.

the Amazon Rainforest suggests that only about $27 \%$ of the PEMA species also occur in the Amazon (Figure 4).

\section{Discussion}

Previous phytosociological studies in the Seasonal Dry Neotropical Forests indicated index rarely exceeding 3.5 [26]. However, the Shannon-Wiener diversity index obtained in this study $\left(H^{\prime}=3.97\right)$, as well the evenness $(J=0.846)$, was higher. These values are equivalent to other studies in well-preserved semideciduous seasonal forest remnants [26]. For example, Pereira et al. [27] obtained a diversity index of $H^{\prime}=3.58$ in a seasonal forest located in the same river basin of the PEMA. Thus, PEMA has a great biodiversity in the shrub-tree strata [28]. Moreover, the diversity estimator proposed by Heltshe and Forrester [20] indicated that the estimated richness was higher than observed richness (Figure 2). Besides, the sample sufficiency measured by the species accumulation curve indicates that it has not reached an asymptote (see Figure 2). Schilling and Ferreira [29] reported that community boundaries in tropical forests are difficult to define, especially due to high species richness, so the curve does not stabilize even with large samples.
The Fabaceae family presented the greater diversity, since it is a characteristic family from seasonal forests, which is well represented in most studies in Atlantic Forest Domain $[29,30]$. In PEMA, the common pattern for forests was observed, where few species are abundant and many species are rare [30]. For example, the 10 species with the highest relative density contributed approximately $40.43 \%$ of the living individuals. Another 39 species contributed to only one individual. However, many of these species can be considered numerically rare only for a given area at a given time but not necessarily from a biological viewpoint [31]. For example, the dominant species Aspidosperma polyneuron is common in semideciduous seasonal forests (SSF) $[32,33]$ but is listed as endangered species because of its high economic value and declining population $[34,35]$.

A total of 54 dead individuals represented about $7 \%$ of the sampled plants and the highest IV (18.87) and RF (7.85) and second largest $\mathrm{RD}$. All these values are considered relatively high when compared to those found in riparian forest (IV =9.92; $\mathrm{RD}=3.88$ ) [27]. The high rate of dead individuals resulted from disturbances like fires, since their thin bark does not tolerate high temperatures; therefore, tree mortality influences the forest dynamics [36]. 


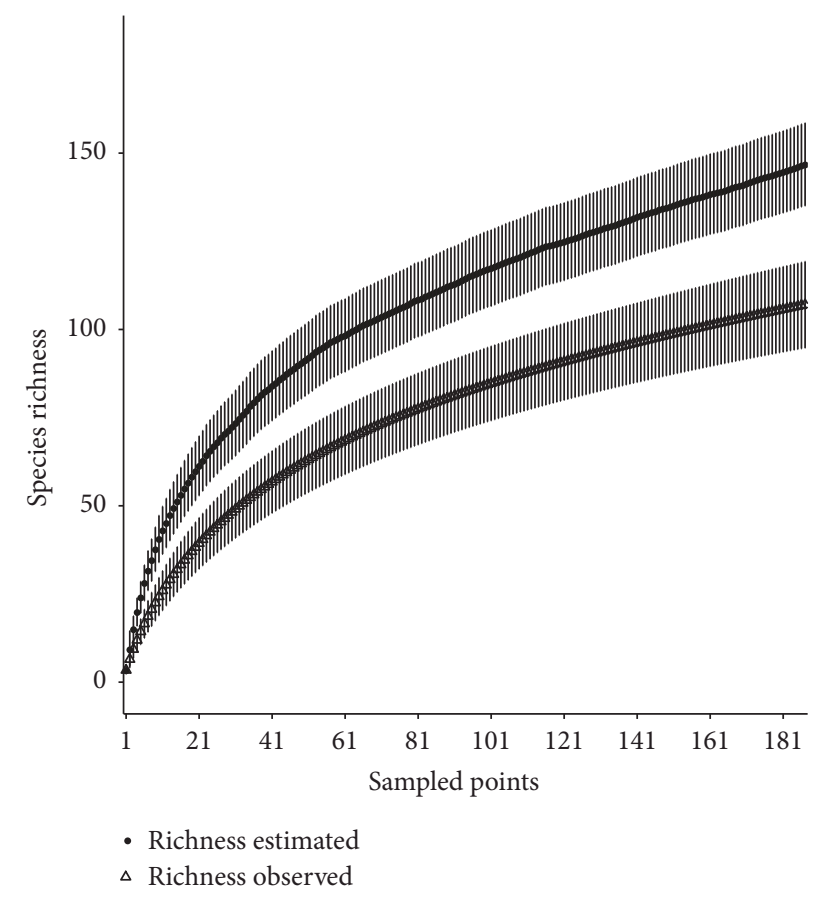

FIGURE 2: Accumulation curves of observed and estimated species from Parque Estadual Mata Atlântica (PEMA). Dots and triangles indicate the species richness; bars indicate confidence intervals $(p<$ $0.05)$.

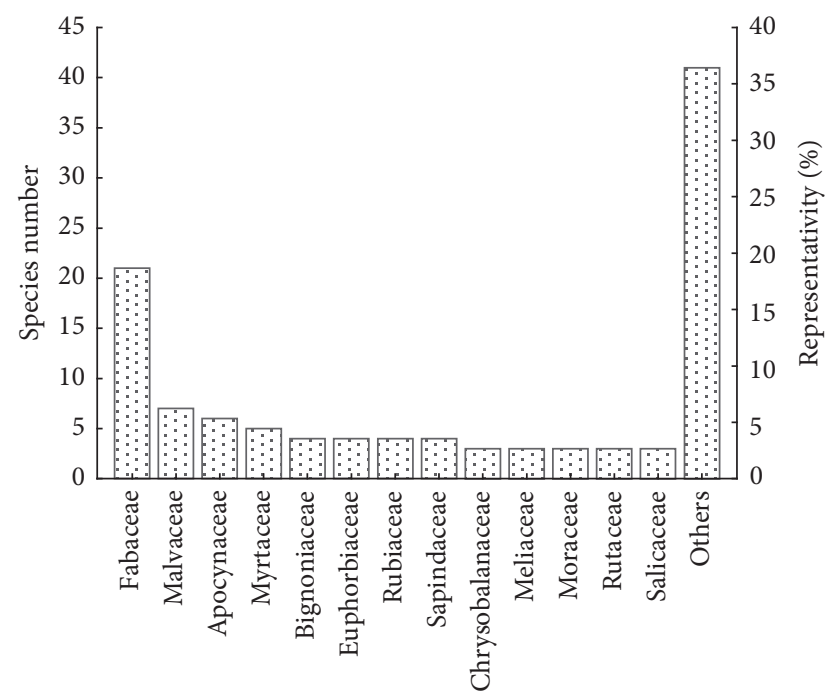

FIgURE 3: The most representative families in species number of the Parque Estadual Mata Atlântica (PEMA), Goiás, Brazil.

For the lianas, the relative density $(\mathrm{RD}=4.15 \%)$ and importance value (IV 8.95) were relatively low, totaling only 31 individuals. However, the lianas can be represented by high percentages $(15-25 \%)$ of the individuals in tropical forests [37]. In the Amazon, the lianas percentages may reach up to $44 \%$ of the forest species, caused mainly by changes in environmental gradients [38]. Thus, like the dead individuals, the lianas influence the dynamics, structure, and the diversity of tropical forests [39]. The increase in density of lianas, mainly due to forest disturbances, becomes an impact indicator $[38,40]$. Although the high densities of lianas can be considered a negative factor to forest [41, 42], lianas are important component of forest ecosystems, originally recognized by Darwin.

The results of cluster analysis showed that about $80 \%$ of the PEMA species were common to the SDNF, and a similarity $>75 \%$ of the PEMA species also occurred in AFD (Figure 4). PEMA is a transitional area between Cerrado and AFD. Thus, PEMA is clearly SDNF belonging to the inland Atlantic Forest Domain [26]. This forest is conditioned to dual climate seasonality: a season with intense summer rains, followed by a dry period $[26,43]$. A total of $68 \%$ of the PEMA species also occurred in Cerrado. The similarity of SDNF to Cerrado was already reported by Françoso et al. [30] who found that the Atlantic Forest Domain has the greatest number of flora shared with the Cerrado, and it is the most important neighboring biome, influencing the Cerrado floristic composition.

The Atlantic Forest Domain is one of the most threatened tropical biomes, with much of the forest in small and isolated remnants (less than $50 \mathrm{ha}$ ) [44]. In general, the AFD is extremely fragmented, with only $11.7 \%$ from its original cover [4], mainly the Seasonal Dry Neotropical Forests [12]. This forest destruction is caused mainly by agricultural expansion [45], occurring in Brazilian central region and ecotones areas of Cerrado and Atlantic Forest Domain [28], resulting in biodiversity loss [11]. This study emphasizes the importance of floristic inventories and biodiversity assessments, necessary to understanding the current richness and conservation of forest biodiversity [43]. Therefore, the biological knowledge is important for guidance of conservation polices [30], and a holistic approach is necessary to solve the conservation problems [46]. Thus, PEMA is extremely important for biological conservation due to attributes such as high biodiversity. For example, in the fauna group, PEMA houses at least 23 species of medium and large mammals, seven of which are listed as endangered in Brazil [47]. For the plant group, this reserve has at least six endangered species [48]. Therefore, this protected area shelters 13 endangered species of plants and animals, showing their importance for biodiversity maintenance.

\section{Conclusions}

PEMA is an important reserve for the conservation of the biodiversity of Seasonal Dry Neotropical Forests, currently threatened by human activities. The reserve contains at least 13 threatened species of plants and animals. In addition, it has a high biodiversity and, because this forest is well conserved, is a priority in conservation and management actions. Thus, this study provides data for the development of a management plan and the conservation of PEMA biodiversity. 
TABLE 1: Phytosociological features of Parque Estadual Mata Atlântica (PEMA), Goiás.

\begin{tabular}{|c|c|c|c|c|c|c|c|}
\hline Species & Biome & Family & $\mathrm{IN}$ & $\mathrm{RD} \%$ & RDo\% & RF\% & IV \\
\hline Dead individuals & - & - & 54 & 7,23 & 3.64 & 7.85 & 18.72 \\
\hline * Aspidosperma polyneuron Müll.Arg. & 1,2 & Apocynaceae & 10 & 1.34 & 15.04 & 1.41 & 17.79 \\
\hline Anadenanthera colubrina (Vell.) Brenan & $1,2,3$ & Fabaceae & 27 & 3.62 & 10.56 & 3.14 & 17.31 \\
\hline Casearia gossypiosperma Briq. & $1,2,3$ & Salicaceae & 57 & 7.63 & 2.35 & 6.12 & 16.10 \\
\hline Myrcia splendens (Sw.) DC. & 1,2 & Myrtaceae & 42 & 5.62 & 1.03 & 5.65 & 12.31 \\
\hline Metrodorea stipularis Mart. & $1,2,3$ & Rutaceae & 33 & 4.42 & 1.96 & 3.93 & 10.31 \\
\hline Hymenaea courbaril L. & $1,2,3$ & Fabaceae & 7 & 0.94 & 7.99 & 0.94 & 9.87 \\
\hline Cariniana estrellensis (Raddi) Kuntze & $1,2,3,4$ & Lecythidaceae & 16 & 2.14 & 5.06 & 2.51 & 9.72 \\
\hline Ceiba speciosa (A. St.-Hil.) Ravenna & $1,2,3$ & Malvaceae & 8 & 1.07 & 6.68 & 1.26 & 9.00 \\
\hline Cipós or lianas & - & - & 31 & 4.15 & 0.41 & 4.40 & 8.95 \\
\hline${ }^{*}$ Apuleia leiocarpa (Vogel) J.F.Macbr. & $1,2,3$ & Fabaceae & 20 & 2.68 & 3.28 & 2.98 & 8.94 \\
\hline${ }^{*}$ Myracrodruon urundeuva Allemão & $1,2,3$ & Anacardiaceae & 28 & 3.75 & 2.38 & 2.67 & 8.80 \\
\hline Syagrus oleracea (Mart.) Becc. & 2 & Arecaceae & 28 & 3.75 & 0.88 & 3.93 & 8.55 \\
\hline Myrcia rostrata DC. & - & Myrtaceae & 27 & 3.62 & 1.14 & 3.14 & 7,90 \\
\hline Attalea phalerata Mart. ex Spreng. & $1,2,3,4$ & Arecaceae & 10 & 1.34 & 4.24 & 1.41 & 6.99 \\
\hline Enterolobium contortisiliquum (Vell.) & $1,2,3$ & Fabaceae & 5 & 0.67 & 5.36 & 0.79 & 6.82 \\
\hline Trichilia claussenii C. DC. & $1,2,3$ & Meliaceae & 22 & 2.95 & 0.84 & 2.67 & 6.46 \\
\hline Terminalia argentea Mart. & $2,3,4$ & Combretaceae & 9 & 1.21 & 3.20 & 1.41 & 5.82 \\
\hline Aspidosperma discolor A. DC. & $1,2,3,4$ & Apocynaceae & 7 & 0.94 & 3.27 & 1.10 & 5.30 \\
\hline Croton floribundus Spreng. & 1,2 & Euphorbiaceae & 14 & 1.87 & 1.40 & 1.88 & 5.16 \\
\hline Casearia rupestris Eichler & $1,2,3$ & Salicaceae & 18 & 2.41 & 0.36 & 2.20 & 4.97 \\
\hline Trichilia catigua A. Juss. & $1,2,3,4$ & Meliaceae & 17 & 2.28 & 0.42 & 2.04 & 4.74 \\
\hline Piptadenia gonoacantha (Mart.) & $1,2,3$ & Fabaceae & 13 & 1.74 & 0.97 & 1.88 & 4.60 \\
\hline Jacaratia spinosa (Aubl.) A.DC. & $1,2,3$ & Caricaceae & 8 & 1.07 & 1.54 & 1.26 & 3.87 \\
\hline Aspidosperma subincannum Mart. & 2,3 & Apocynaceae & 13 & 1.74 & 0.33 & 1.57 & 3.64 \\
\hline Aspidosperma eburneum Allemão ex Sal. & 1,4 & Apocynaceae & 6 & 0.80 & 1.57 & 0.94 & 3.31 \\
\hline Celtis iguanaea (Jacq.) Sarg. & $1,2,3$ & Cannabaceae & 10 & 1.34 & 0.35 & 1.26 & 2.94 \\
\hline Dilodendron bipinnatum Radlk. & 2,3 & Sapindaceae & 8 & 1.07 & 0.57 & 1.26 & 2.90 \\
\hline Tabebuia roseoalba (Ridl.) Sandwith & 1,2 & Bignoniaceae & 10 & 1.34 & 0.33 & 1.10 & 2.77 \\
\hline Unidentified species 5 & - & - & 8 & 1.07 & 0.65 & 0.63 & 2.35 \\
\hline Licania alba (Bernoulli) Cuatrec. & - & Chrysobalanaceae & 8 & 1.07 & 0.28 & 0.94 & 2.29 \\
\hline Apeiba tibourbou Aubl. & $2,3,4$ & Malvaceae & 6 & 0.80 & 0.53 & 0.94 & 2.28 \\
\hline Cordiera sessilis (Vell.) Kuntze & 2,3 & Rubiaceae & 6 & 0.80 & 0.21 & 0.94 & 1.95 \\
\hline Copaifera langsdorffii Desf. & $1,2,3$ & Fabaceae & 4 & 0.54 & 0.68 & 0.63 & 1.84 \\
\hline Guazuma ulmifolia Lam. & $1,2,3,4$ & Sapotaceae & 5 & 0.67 & 0.38 & 0.79 & 1.84 \\
\hline${ }^{*}$ Cedrela fissilis Vell. & $1,2,3$ & Meliaceae & 5 & 0.67 & 0.38 & 0.79 & 1.83 \\
\hline Schefflera morototoni (Aubl.) Maguire & $1,2,3,4$ & Araliaceae & 4 & 0.54 & 0.62 & 0.63 & 1.78 \\
\hline Protium heptaphyllum (Aubl.) Marchand & $1,2,3,4$ & Burseraceae & 4 & 0.54 & 0.60 & 0.63 & 1.77 \\
\hline Rhamnidium elaeocarpum Reissek & $1,2,3$ & Rhamnaceae & 5 & 0.67 & 0.24 & 0.79 & 1.69 \\
\hline Bauhinia forficata Link & $1,2,3$ & Fabaceae & 5 & 0.67 & 0.14 & 0.79 & 1.59 \\
\hline Inga edulis Mart. & 1,2 & Fabaceae & 5 & 0.67 & 0.29 & 0.63 & 1.59 \\
\hline Qualea parviflora Mart. & 3 & Vochysiaceae & 4 & 0.54 & 0.39 & 0.63 & 1.55 \\
\hline Alibertia edulis (Rich.) A. Rich. ex DC. & $1,2,3,4$ & Rubiaceae & 5 & 0.67 & 0.08 & 0.79 & 1.53 \\
\hline Pouteria torta (Mart.) Radlk. & 3,4 & Sapindaceae & 4 & 0.54 & 0.24 & 0.63 & 1.40 \\
\hline Unonopsis guatterioides (A. DC.) R.E. Fr. & $1,2,3,4$ & Annonaceae & 4 & 0.54 & 0.20 & 0.63 & 1.36 \\
\hline Cardiopetalum calophyllum Schltdl. & $1,2,3,4$ & Annonaceae & 4 & 0.54 & 0.19 & 0.63 & 1.35 \\
\hline Erythrina verna Vell. & 1 & Fabaceae & 4 & 0.54 & 0.13 & 0.63 & 1.30 \\
\hline Eugenia leitonii D. Legrand & 1 & Myrtaceae & 2 & 0.27 & 0.71 & 0.31 & 1.30 \\
\hline Ouratea castaneifolia (DC.) Engl. & $1,2,3$ & Ochnaceae & 4 & 0.54 & 0.10 & 0.63 & 1.26 \\
\hline${ }^{*}$ Astronium fraxinifolium Schott & 2,3 & Anacardiaceae & 4 & 0.54 & 0.06 & 0.63 & 1.22 \\
\hline Matayba guianensis Aubl. & $1,2,3,4$ & Sapindaceae & 3 & 0.40 & 0.48 & 0.31 & 1.20 \\
\hline Inga vera Willd. & $1,2,3$ & Fabaceae & 4 & 0.54 & 0.11 & 0.47 & 1.12 \\
\hline Cecropia pachystachya Trécul & $1,2,3,4$ & Urticaceae & 3 & 0.40 & 0.19 & 0.47 & 1.06 \\
\hline
\end{tabular}


TABle 1: Continued.

\begin{tabular}{|c|c|c|c|c|c|c|c|}
\hline Species & Biome & Family & IN & $\mathrm{RD} \%$ & RDo $\%$ & RF\% & IV \\
\hline Trema micrantha (L.) Blume & $1,2,3$ & Cannabaceae & 4 & 0.54 & 0.05 & 0.47 & 1.06 \\
\hline Diospyros inconstans Jacq. & $1,2,3,4$ & Ebenaceae & 3 & 0.40 & 0.16 & 0.47 & 1.03 \\
\hline Handroanthus impetiginosus (Mart. ex DC.) & $1,2,3$ & Bignoniaceae & 2 & 0.27 & 0.43 & 0.31 & 1.02 \\
\hline Myrocarpus peruiferum L.F. & $1,2,4$ & - & 3 & 0.40 & 0.08 & 0.47 & 0.95 \\
\hline Luehea divaricata Mart. \& Zucc. & $1,2,3$ & Malvaceae & 1 & 0.13 & 0.63 & 0.16 & 0.92 \\
\hline Albizia polycephala (Benth.) Killip & 1,2 & Fabaceae & 2 & 0.27 & 0.25 & 0.31 & 0.83 \\
\hline Sterculia striata A. St.-Hil. \& Naudin & $2,3,4$ & Malvaceae & 2 & 0.27 & 0.23 & 0.31 & 0.81 \\
\hline Cupania vernalis Cambess. & $1,2,3$ & Sapindaceae & 3 & 0.40 & 0.09 & 0.31 & 0.81 \\
\hline Drimys brasiliensis Miers & $1,2,4$ & Winteraceae & 3 & 0.40 & 0.06 & 0.31 & 0.77 \\
\hline Sapium glandulosum (L.) Morong & $1,2,3$ & Euphorbiaceae & 2 & 0.27 & 0.19 & 0.31 & 0.77 \\
\hline Styrax camporum Pohl. & 1,2 & Sterculiaceae & 2 & 0.27 & 0.16 & 0.31 & 0.75 \\
\hline Matayba guianensis Aubl. & 1,4 & Sapindaceae & 2 & 0.27 & 0.14 & 0.31 & 0.72 \\
\hline Piper aduncum L. & $1,2,3,4$ & Piperaceae & 2 & 0.27 & 0.09 & 0.31 & 0.67 \\
\hline Albizia niopoides (Spruce ex Benth.) & $1,2,3$ & Fabaceae & 2 & 0.27 & 0.08 & 0.31 & 0.67 \\
\hline Zanthoxylum rhoifolium Lam. & $1,2,3$ & Rutaceae & 2 & 0.27 & 0.06 & 0.31 & 0.65 \\
\hline Ficus citrifolia Mill. & $1,2,3$ & Moraceae & 2 & 0.27 & 0.06 & 0.31 & 0.64 \\
\hline Psidium cattleianum Afzel. ex Sabine & 1,2 & Myrtaceae & 3 & 0.40 & 0.03 & 0.16 & 0.59 \\
\hline Styrax pohlii A. DC. & 3 & Styracaceae & 1 & 0.13 & 0.30 & 0.16 & 0.59 \\
\hline Unidentified species 3 & - & - & 1 & 0.13 & 0.26 & 0.16 & 0.55 \\
\hline Luehea grandiflora Mart. & $2,3,4$ & Malvaceae & 1 & 0.13 & 0.20 & 0.16 & 0.49 \\
\hline Sloanea guianensis (Aubl.) Benth. & 1,2 & Elaeocarpaceae & 1 & 0.13 & 0.19 & 0.16 & 0.48 \\
\hline Maclura tinctoria (L.) D.Don ex Steud. & $1,2,3,4$ & Moraceae & 1 & 0.13 & 0.18 & 0.16 & 0.47 \\
\hline Hymenolobium petraeum Ducke & - & Fabaceae & 1 & 0.13 & 0.17 & 0.16 & 0.46 \\
\hline Zanthoxylum riedelianum Engl. & $1,2,3$ & Rutaceae & 2 & 0.27 & 0.02 & 0.16 & 0.44 \\
\hline Nectandra lanceolata Nees \& Mart. & $1,2,3$ & Lauraceae & 1 & 0.13 & 0.11 & 0.16 & 0.40 \\
\hline Andira anthelmia (Vell.) J.F.Macbr. & 1 & Fabaceae & 1 & 0.13 & 0.10 & 0.16 & 0.39 \\
\hline Hirtella glandulosa Spreng. & $1,2,3,4$ & Chrysobalanaceae & 1 & 0.13 & 0.08 & 0.16 & 0.37 \\
\hline Sorocea bonplandii (Baill.) W.C.Burger & $1,2,3$ & Moraceae & 1 & 0.13 & 0.06 & 0.16 & 0.35 \\
\hline Platypodium elegans Vogel & 2,3 & Fabaceae & 1 & 0.13 & 0.06 & 0.16 & 0.35 \\
\hline Inga cylindrica (Vell.) Mart. & 1 & Fabaceae & 1 & 0.13 & 0.06 & 0.16 & 0.35 \\
\hline Aralia warmingiana (Marchal) J. Wen & $1,2,3,4$ & Araliaceae & 1 & 0.13 & 0.05 & 0.16 & 0.34 \\
\hline Cnidoscolus urens (L.) Arthur & 1,2 & Euphorbiaceae & 1 & 0.13 & 0.05 & 0.16 & 0.34 \\
\hline Agonandra brasiliensis Miers ex Benth. & 1,2 & Opiliaceae & 1 & 0.13 & 0.04 & 0.16 & 0.33 \\
\hline Handroanthus ochraceus (Cham.) Mattos & 3 & Bignoniaceae & 1 & 0.13 & 0.03 & 0.16 & 0.33 \\
\hline Roupala montana (Huber) K.S. Edwards & 3 & Proteaceae & 1 & 0.13 & 0.03 & 0.16 & 0.33 \\
\hline Aloysia virgata (Ruiz \& Pav.) Juss. & 1,2 & Verbenaceae & 1 & 0.13 & 0.03 & 0.16 & 0.32 \\
\hline Croton urucurana Baill. & 1,2 & Euphorbiaceae & 1 & 0.13 & 0.02 & 0.16 & 0.32 \\
\hline Unidentified species 1 & - & - & 1 & 0.13 & 0.02 & 0.16 & 0.31 \\
\hline Himatanthus sucuuba (Spruce ex Müll.) & 4 & Apocynaceae & 1 & 0.13 & 0.01 & 0.16 & 0.30 \\
\hline Handroanthus vellosoi (Toledo) Mattos & $1,2,3$ & Bignoniaceae & 1 & 0.13 & 0.01 & 0.16 & 0.30 \\
\hline Hirtella glabrata Pilg. & 2 & Chrysobalanaceae & 1 & 0.13 & 0.01 & 0.16 & 0.30 \\
\hline Terminalia glabrescens Mart. & $1,2,3$ & Combretaceae & 1 & 0.13 & 0.01 & 0.16 & 0.30 \\
\hline Inga sessilis (Vell.) Mart. & 2,3 & Fabaceae & 1 & 0.13 & 0.01 & 0.16 & 0.30 \\
\hline Cordiera macrophylla (K.Schum.) Kuntze & 2,3 & Rubiaceae & 1 & 0.13 & 0.01 & 0.16 & 0.30 \\
\hline Unidentified species 2 & - & - & 1 & 0.13 & 0.01 & 0.16 & 0.30 \\
\hline Aspidosperma sp. & - & Apocynaceae & 1 & 0.13 & 0.01 & 0.16 & 0.30 \\
\hline Erythrina falcata Benth. & 1,2 & Fabaceae & 1 & 0.13 & 0.01 & 0.16 & 0.30 \\
\hline Luehea paniculata Mart. & $1,2,3$ & Malvaceae & 1 & 0.13 & 0.01 & 0.16 & 0.30 \\
\hline Piper tuberculatum Jacq. & $2,3,4$ & Piperaceae & 1 & 0.13 & 0.01 & 0.16 & 0.30 \\
\hline Tocoyena formosa (Cham. \& Schltdl.) & 2,3 & Rubiaceae & 1 & 0.13 & 0.01 & 0.16 & 0.30 \\
\hline Unidentified species 4 & - & - & 1 & 0.13 & 0.01 & 0.16 & 0.30 \\
\hline Croton floribundus Spreng. & 1,2 & Euphorbiaceae & 1 & 0.13 & 0.01 & 0.16 & 0.30 \\
\hline Pseudobombax tomentosum (Mart. \& Zucc.) & 2,3 & Malvaceae & 1 & 0.13 & 0.01 & 0.16 & 0.30 \\
\hline
\end{tabular}


TABLE 1: Continued.

\begin{tabular}{|c|c|c|c|c|c|c|c|}
\hline Species & Biome & Family & IN & $\mathrm{RD} \%$ & RDo\% & $\mathrm{RF} \%$ & IV \\
\hline Myrcia undulata O.Berg & 1 & Myrtaceae & 1 & 0.13 & 0.01 & 0.16 & 0.30 \\
\hline Casearia decandra Jacq. & 1,2 & Salicaceae & 1 & 0.13 & 0.01 & 0.16 & 0.30 \\
\hline Pterodon emarginatus Vogel & 1 & Fabaceae & 1 & 0.13 & 0.01 & 0.16 & 0.30 \\
\hline Dipteryx alata Vogel & 1 & Fabaceae & 1 & 0.13 & 0.01 & 0.16 & 0.13 \\
\hline${ }^{*}$ Bowdichia virgilioides Kunt & 1 & Fabaceae & 1 & 0.13 & 0.01 & 0.16 & 0.13 \\
\hline
\end{tabular}

1: Atlantic Forest (AF); 2: Seasonal Dry Neotropical Forest (SDNF); 3: Cerrado; 4: Amazonian Rainforest. NI: number of individuals; RD: relative density (\%); RDo: relative dominance (\%); RF: relative frequency (\%); IV: importance value. ${ }^{*}$ Endangered species in the PEMA. The categorization of the main phytophysiognomy in which the species occurs followed Oliveira-Filho and Fontes (2000), Ratter et al. (2003), Oliveira-Filho et al. (2005), and Lorenzi (2014, 2016ab).

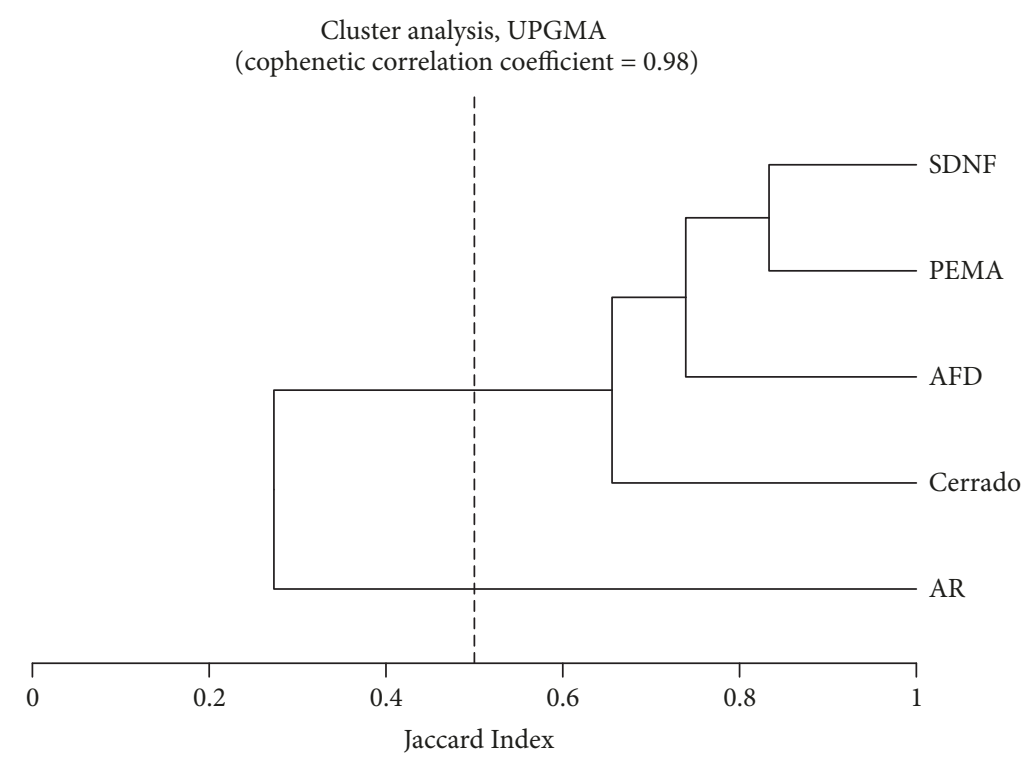

Figure 4: Cluster analysis for correlation of PEMA vegetation and Atlantic Forest Domain (AFD), Amazonian Rainforest (AR), Cerrado, and Seasonal Dry Neotropical Forest (SDNF).

\section{Conflicts of Interest}

The authors declare that there are no conflicts of interest regarding the publication of this manuscript.

\section{Acknowledgments}

The authors acknowledge "Secretaria do Meio Ambiente, Recursos Hídricos, Infraestrutura, Cidades, e Assuntos Metropolitanos (SECIMA)" for granting the license for the study of PEMA. The authors also acknowledge "Pró-Reitoria de Pesquisa e Pós-Graduação (PrP) da Universidade Estadual de Goiás (UEG)" for the scientific initiation scholarship to Jovan Martins Rios.

\section{References}

[1] M. Tabarelli, C. A. Peres, and F. P. L. Melo, "“few winners and many losers" paradigm revisited: emerging prospects for tropical forest biodiversity," Biological Conservation, vol. 155, pp. 136-140, 2012.
[2] N. Myers, R. A. Mittermeler, C. G. Mittermeler, G. A. B. da Fonseca, and J. Kent, "Biodiversity hotspots for conservation priorities," Nature, vol. 403, no. 6772, pp. 853-858, 2000.

[3] R. C. Forzza, J. F. A. Baumgratz, C. E. M. Bicudo et al., Catálogo de Plantas e Fungos do Brasil, Rio de Janeiro: Jardim Botânico do Rio e Janeiroe, 1st edition, 2010.

[4] M. C. Ribeiro, J. P. Metzger, A. C. Martensen, F. J. Ponzoni, and M. M. Hirota, "The Brazilian Atlantic forest: how much is left, and how is the remaining forest distributed? Implications for conservation," Biological Conservation, vol. 142, no. 6, pp. 11411153, 2009.

[5] IBGE, Manual Técnico da Vegetação Brasileira, Instituto Brasileiro de Geografia e Estatística, 2012.

[6] J. R. Stehmann, R. C. Forzza, A. Salino, M. Sobral, D. Pinheiro, and L. H. Y. Kamino, Eds., Plantas da Floresta Atlântica, Rio de Janeiro: Jardim Botânico do Rio de Janeiro, 2009.

[7] R. T. Pennington, M. Lavin, and A. Oliveira-Filho, "Woody plant diversity, evolution, and ecology in the tropics: perspectives from seasonally dry tropical forests," Annual Review of Ecology, Evolution and Systematics, vol. 40, no. 7th, pp. 437-457, 2009. 
[8] A. T. Oliveira-Filho, J. A. Jarenkow, and M. J. N. Rodal, "Floristic relationships of seasonally dry forests of eastern South America based on tree distribution patterns," in Neotropical Savannas and Seasonally Dry Forests: Plant Diversity, Biogeography, and Conservation, J. A. Pennington, R. T. Lewis, and G. P. Ratter, Eds., pp. 159-192, CRS Press, Edinburg, UK, 2006.

[9] B. A. Pereira, F. Venturoli, and F. A. Carvalho, "Florestas estacionais no cerrado: uma visão geral," Pesquisa Agropecuária Tropical, vol. 41, no. 3, pp. 446-455, 2011.

[10] T. W. Gillespie, B. Lipkin, L. Sullivan, D. R. Benowitz, S. Pau, and G. Keppel, "The rarest and least protected forests in biodiversity hotspots," Biodiversity and Conservation, vol. 21, no. 14, pp. 3597-3611, 2012.

[11] B. Doug, E. Pipa, L. Katherine, M. May-Tobin, S. Roquemore, and E. Saxon, The Root of the Problem, UCS Publications, Cambridge, UK, 2011.

[12] R. F. Haidar, J. M. Fagg, J. R. Pinto et al., "Florestas estacionais e áreas de ecótono no estado do Tocantins, Brasil: parâmetros estruturais, classificação das fitofisionomias florestais e subsídios para conservação," Acta Amazonica, vol. 43, no. 3, pp. 261-290, 2013

[13] A. M. Z. Martini, P. A. Fiaschi, A. M. Amorin, and J. L. Paixão, "A hot-point within a hot-spot: a high diversity site in Brazil's Atlantic Forest," Biodiversity and Conservation, vol. 16, no. 11, pp. 3111-3128, 2007.

[14] I. M. Pereira, V. L. Gomes-Klein, and M. Groppo, "Distribution and conservation of davilla (dilleniaceae) in Brazilian Atlantic Forest using ecological niche modeling," International Journal of Ecology, vol. 2014, Article ID 819739, 2014.

[15] M. Q. Matos and J. M. Felfili, "Florística, fitossociologia e diversidade da vegetação arbórea nas matas de galeria do Parque Nacional de Sete Cidades (PNSC), Piauí, Brasil," Acta Botanica Brasilica, vol. 24, no. 2, pp. 483-496, 2010.

[16] IBGE, Instituto Brasileiro de Geografia e Estatística. 2006. Mapas de Solo do Brasil. Mapas de Unidade de Relevo do Brasil. Disponível em: <ftp://geoftp.ibge.gov.br/mapas_tematicos/ mapas_murais $>$.

[17] C. A. Alvares, J. L. Stape, P. C. Sentelhas, J. L. De Moraes Gonçalves, and G. Sparovek, “Köppen's climate classification map for Brazil," Meteorologische Zeitschrift, vol. 22, no. 6, pp. 711-728, 2013.

[18] A. E. Magurran, Ecological Diversity and its Measurement, Princeton University Press, London, UK, 1988.

[19] D. Muller-Dombois and H. Ellenberg, Aims and Methods of Vegetation Ecology, John Wiley \& Sons, New York, NY, USA, 1974.

[20] J. F. Heltshe and N. E. Forrester, "Estimating species richness using the jackknife procedure.," Biometrics, vol. 39, no. 1, pp. 1$11,1983$.

[21] R. K. Colwell, A. Chao, N. J. Gotelli et al., "Models and estimators linking individual-based and sample-based rarefaction, extrapolation and comparison of assemblages," Journal of Plant Ecology, vol. 5, no. 1, pp. 3-21, 2012.

[22] D. A. Carvalho, A. T. Oliveira-Filho, E. d. Vilela, and N. Curi, "Florística e estrutura da vegetação arbórea de um fragmento de floresta semidecedual às margens do reservatório da usina hidrelétrica Dona Rita (Itambé do Mato Dentro, MG)," Acta Botanica Brasilica, vol. 14, no. 1, pp. 37-55, 2000.

[23] H. Lorenzi, Árvores Brasileiras, Instituto Plantarum, Nova Odessa, Brazil, 6 edition, 2014.

[24] H. Lorenzi, Árvores Brasileiras, Instituto Plantarum, Nova Odessa, Brazil, 7 edition, 2016.
[25] M. W. Chase, M. J. M. Christenhusz, M. F. Fay et al., "An update of the Angiosperm Phylogeny Group classification for the orders and families of flowering plants: APG IV," Botanical Journal of the Linnean Society, vol. 181, no. 1, pp. 1-20, 2016.

[26] S. d. Lopes, I. Schiavini, A. P. Oliveira, and V. S. Vale, "An ecological comparison of floristic composition in seasonal semideciduous forest in Southeast Brazil: implications for conservation," International Jounal of Forest Research, vol. 2012, 2012.

[27] I. Pereira, G. Jerônimo, K. Fonseca, and A. Coneglian, "Floristic and phytosociological study of gallery forest in Cerrado," Revista Agrotecnologia - Agrotec, vol. 6, no. 2, pp. 1-19, 2015.

[28] N. S. Soares, C. A. Gonçalves, G. M. Araújo, and C. Lomônaco, "Floristic composition and abundance in forest fragments: a case study from Southern Goiás, Brazil," Bioscience Journal, vol. 31, no. 4, pp. 1238-1252, 2015.

[29] A. C. Schilling and L. Ferreira, "Curva de acumulação de espécies e suficiência amostral em florestas tropicais," Revista Brasileira de Botânica, vol. 31, pp. 179-187, 2008.

[30] R. D. Françoso, R. F. Haidar, and R. B. Machado, “Tree species of South America central savanna: endemism, marginal areas and the relationship with other biomes," Acta Botanica Brasilica, vol. 30, no. 1, pp. 78-86, 2016.

[31] A. N. Oliveira and I. L. Amaral, "Florística e fitossociologia de uma floresta de vertente na Amazônia Central, Amazonas, Brasil," Acta Amazonica, vol. 34, no. 1, pp. 21-34, 2004.

[32] Y. R. Boloventa, Populações Arbóreas Nativas Estão Regenerando no Maior Fragmento de Floresta Estacional Semidecidual do Norte do Paraná, Universidade Estadual de Londrina, Londrina, Brazil, 2009.

[33] L. A. B. Jorge, T. M. Millani, R. C. B. Fonseca, and A. A. Arruda, "Diameter structure and spatial arrangement of the most abundant species in a seasonal semideciduous forest fragment in Botucatu, Southeastern Brazil," Floresta e Ambiente, vol. 22, no. 3, pp. 355-367, 2015.

[34] G. Martinelli, T. Messina, and T. M. L. S. Filho, Livro vermelho da flora do Brasil - Plantas raras do Cerrado, vol. 1, Rio de Janeiro: Andrea Jakobsson : Instituto de Pesquisas Jardim Botânico do Rio de Janeiro : CNCFlora, 1st edition, 2014.

[35] G. Martinelli and M. A. Morais, Livro Vermelho da Flora do Brasil,.

[36] W. A. Hoffmann, R. Adasme, M. Haridasan et al., “Tree topkill, not mortality, governs the dynamics of savanna-forest boundaries under frequent fire in central Brazil," Ecology, vol. 90, no. 5, pp. 1326-1337, 2009.

[37] C. B. Murray-Smith, N. A. Brummitt, A. T. Oliveira-Filho et al., "Plant diversity hotspots in the Atlantic coastal forests of Brazil," Conservation Biology, vol. 23, no. 1, pp. 151-163, 2009.

[38] E. A. Oliveira, B. S. Marimon, T. R. Feldpausch et al., "Diversity, abundance and distribution of lianas of the CerradoAmazonian forest transition," Plant Ecology Diversity, vol. 7, no. 1-2, pp. 231240, 2017.

[39] L. G. Lohmann, C. D. Bell, M. F. Calió, and R. C. Winkworth, "Pattern and timing of biogeographical history in the Neotropical tribe Bignonieae (Bignoniaceae)," Botanical Journal of the Linnean Society, vol. 171, no. 1, pp. 154-170, 2013.

[40] B. L. P. Villagra, E. P. C. Gomes, R. J. Burnham, and S. R. Neto, "Diversity and abundance of climbers from the Atlantic Forest, Southeastern Brazil," Biodiversity and Conservation, vol. 22, no. 11, pp. 2505-2517, 2013. 
[41] A. N. Oliveira, I. L. Amaral, M. B. Ramos, and K. M. Formiga, "Aspectos florísticos e ecológicos de grandes lianas em três ambientes florestais de terra firme na Amazônia Central," Acta Amazonica, vol. 38, no. 3, pp. 421-430, 2008.

[42] S. A. Schnitzer and F. Bongers, "Increasing liana abundance and biomass in tropical forests: emerging patterns and putative mechanisms," Ecology Letters, vol. 14, no. 4, pp. 397-406, 2011.

[43] S. Jayakumar, S. S. Kim, and J. Heo, "Floristic inventory and diversity assessment - a critical review," Proceedings of the National Academy of Ecology and Environmental Sciences, vol. 1, pp. 151-168, 2011.

[44] P. K. Lira, L. R. Tambosi, R. M. Ewers, and J. P. Metzger, "Landuse and land-cover change in Atlantic Forest landscapes," Forest Ecology and Management, vol. 278, pp. 80-89, 2012.

[45] B. Phalan, M. Bertzky, S. H. M. Butchart et al., "Crop expansion and conservation priorities in tropical countries," PLOS ONE, vol. 8, no. 1, Article ID e51759, 2013.

[46] D. Lindenmayer and M. Hunter, "Some guiding concepts for conservation biology," Conservation Biology, vol. 24, no. 6, pp. 1459-1468, 2010.

[47] E. C. Rocha, K. L. Soares, and I. M. Pereira, "Medium-and large-sized mammals in Mata Atlântica State Park, southeastern Goiás, Brazil," Check List, vol. 11, no. 6, article no. 1801, 2015.

[48] G. Martinelli and M. A. Morais, Livro Vermelho da Flora do Brasil, Instituto de Pesquisas do Jardim Botânico do Rio de Janeiro, 2013. 

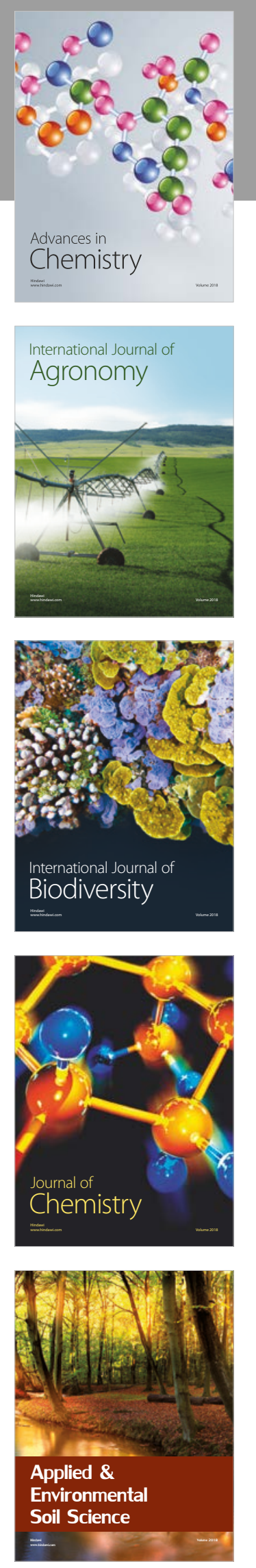

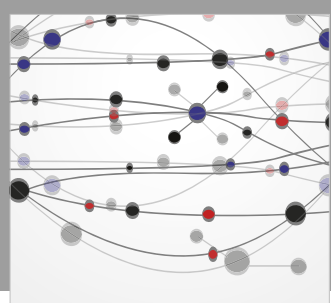

The Scientific World Journal

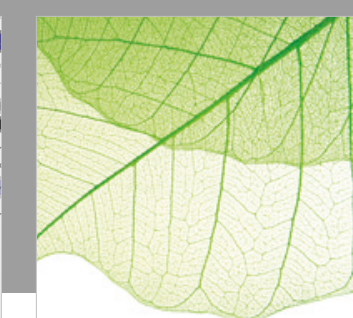

Journal of Botany

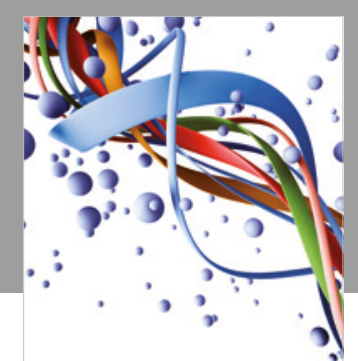

Scientifica

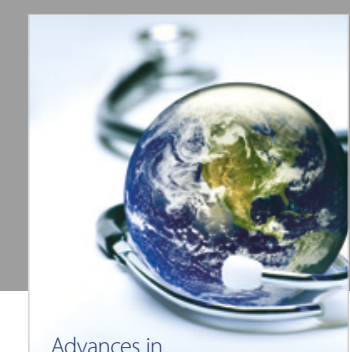

Public Health

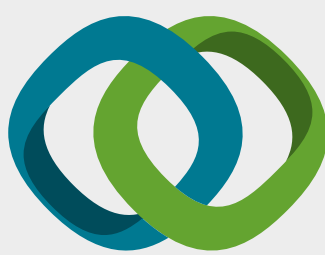

Hindawi

Submit your manuscripts at

www.hindawi.com
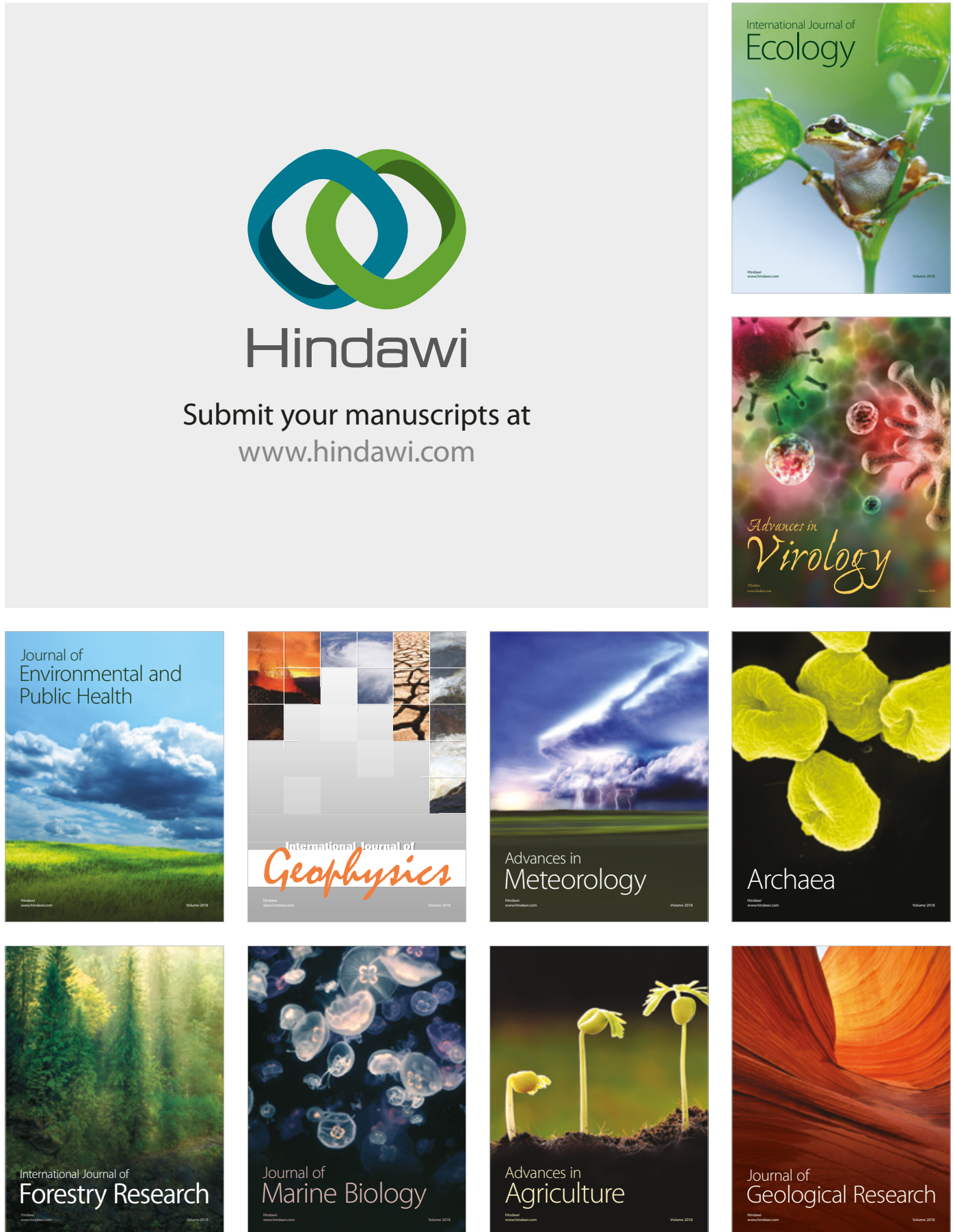

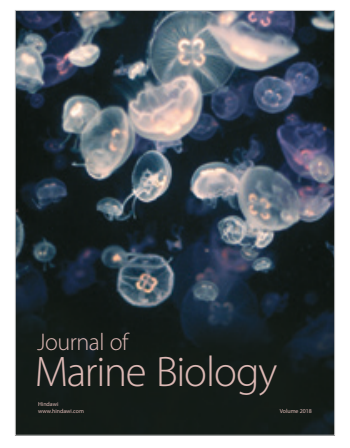

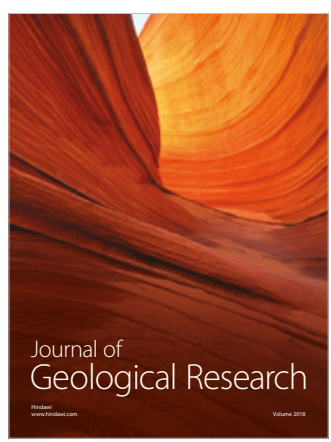

